\title{
AUTENTISITAS SUMBER SEJARAH PANCASILA DALAM MASA SIDANG PERTAMA BADAN UNTUK MENYELIDIKI USAHA-USAHA PERSIAPAN KEMERDEKAAN TANGGAL 29 MEI-1 JUNI 1945
}

\author{
Aris Hardinanto \\ email: aris@trunojoyo.ac.id
}

\begin{abstract}
This article seeks to compares different ideas concerning Indonesian statehood as put forth by our founding father in sessions of the Dokuritsu Zyunbi Tyosa Kai (Investigating Body for Preparing Indonesia's Independence). The author notes that there is doubt as of the authenticity of documents recording the debates and the speeches made during meetings held by this body (28 may-1 June 1945 \& 10 July-17 July 1945). On one side, there is the preparatory documents of the 1945 Constitution as issued by Muhammad Yamin and which is regarded by the State Secretariat as the one and only authentic source (from 1959-1992). On the other hand, notes collected by Pringgodigdo and Yamin was latter used as the basis for the publication of the Body's minutes of meetings in 1995. The author observes that both collections (Yamin and Pringodidgo) differs in its exposure of ideas on the Indonesian statehood put forth during the Body's meetings.
\end{abstract}

Keywords:

preparatory documents, Pringodigdo's collection, Yamin's collection, Pancasila

\begin{abstract}
Abstrak
Tulisan ini hendak membandingkan risalah dari sidang-sidang Dokuritu Zyunbi Tyosa Kai atau dikenal dengan sebutan Badan Untuk Menyelidiki Usaha Persiapan Kemerdekaan (28 Mei 1945-1 Juni 1945 dan 10 Juli 1945-17 Juli 1945). Penulis mencatat adanya keraguan akan auntentisitas dari dokumen atau risalah rapat-rapat Badan ini. Pada satu pihak, Naskah Persiapan Undangundang Dasar 1945 karya Muhammad Yamin oleh Sekretariat Negara dianggap sumber yang autentik sehingga dijadikan satu-satunya sumber penerbitan Risalah Badan Penyelidik Usahausaha Persiapan Kemerdekaan sejak tahun 1959 hingga tahun 1992. Pada lain pihak, pada 1995 diterbitkan edisi ketiga yang memuat perbandingan naskah BPUPKI koleksi Pringgodigdo dengan koleksi Yamin. Catatan yang dapat dibuat adalah adanya perbedaan prinsipil tentang usulan dasar Indonesia merdeka antara kedua koleksi di atas.
\end{abstract}

Kata kunci: naskah persiapan, koleksi Pringgodigdo, koleksi Yamin, Pancasila

\section{Pendahuluan}

Kemerdekaan pada hakikatnya merupakan hak setiap bangsa yang ada di dunia, tanpa terkecuali. Indonesia dalam meraih kemerdekaannya melalui dua usaha, yaitu usaha diplomasi dan konfrontasi. Perjalanan meraih kemerdekaan sejak zaman penjajahan Belanda dan pendudukan Jepang dipandang sebagai sebuah fase sejarah. 
Sejarah menurut Kamus Besar Bahasa Indonesia ${ }^{1}$ salah satu artinya adalah kejadian dan peristiwa yang benar-benar terjadi pada masa lampau. Artinya segala bentuk peristiwa atau hal-hal yang berkaitan dengan usaha-usaha bangsa Indonesia ketika akan meraih kemerdekaan, berdasarkan arti istilah Kamus Besar Bahasa Indonesia dapat disebut sebagai sejarah.

Jepang mendarat di Hindia Belanda pertama kali pada tanggal 10 November 1942.2 Masa pendudukan Jepang dapat dianggap sebagai masa dimana secara formal usaha-usaha untuk meraih kemerdekaan diselenggarakan. Pada masa pendudukan Jepang di Indonesia, kemudian di tengah terdesaknya Jepang dalam peperangan Asia Timur Raya, dijanjikan kepada Indonesia bahwa akan dimerdekakan oleh Jepang suatu hari nanti. Realisasi janji tersebut ditandai dengan dibentuknya Dokuritu Zyunbi Tyosa Kai pada tanggal 29 April $1945 .^{3}$

Badan dengan nama Jepang Dokuritu Zyunbi Tyosa Kai sering diterjemahkan sebagai Badan Penyelidik Usaha Persiapan Kemerdekaan Indonesia (selanjutnya disebut BPUPK), tambahan kata Indonesia kurang tepat karena kata tersebut tidak ada dalam istilah aslinya. BPUPK memiliki dua masa sidang, yaitu masa sidang pertama pada tanggal 29 Mei 1945 sampai 1 Juni 1945 dan masa sidang kedua pada tanggal 10 Juli 1945 sampai 17 Juli 1945.. Anggota BPUPK terdiri atas Kaityo (Ketua), Fuku Kaityoo (Wakil Ketua), 60 orang Iin (anggota) ditambah 8 orang Tokubetu Iin (anggota kehormatan) dari pihak Jepang. Jalannya persidangan dicatat oleh para notulis dan stenografer yang disediakan oleh Tata Usaha BPUPK. Mereka mengambil notulen dengan tulisan tangan biasa tetapi juga dengan steno. Pidato yang jelas diambil dengan steno ialah pidato Ir. Soekarno yang kemudian dikenal dengan pidato "Lahirnya Pancasila". Tipe stenografinya kemudian dikenal sebagai stenografi sistem Karundeng. ${ }^{5}$

1 http://kbbi.web.id/sejarah, diakses 22 Januari 2017

2 A. G. Pringgodigdo, Tatanegara di Djawa Pada Waktu Pendudukan Djepang dari Bulan Maret sampai bulan Desember 1942, Jajasan Fonds Universitit Negeri Gadjah Mada, Jogkajarta, 1952, hlm., 5 .

3 A.B. Kusuma, Lahirnya Undang-undang Dasar 1945, Badan Penerbit Fakultas Hukum Universitas Indonesia, Jakarta, 2009, hlm., 10.

${ }^{4}$ Id., hlm. 457

${ }^{5}$ Lembaga Soekarno-Hatta, Sejarah Lahirnya Undang-Undang Dasar 1945 dan Pancasila, Jakarta, 1986, hlm., 32. 
Kebenaran pidato-pidato anggota BPUPK yang diambil dengan menggunakan stenografi tersebut juga diperkuat dengan keterangan dari dua stenografer BPUPK, yaitu Sumarti T.B. Simatupang dan Netty Karundeng. Menurut mereka berdua, setelah stenogram tersebut selesai dikumpulkan, kemudian diketik. ${ }^{6}$ Kelak salah satu salinan stenografi tersebut dipinjam oleh Muhammad Yamin dari Wakil Ketua Tata Usaha BPUPK A.G. Pringgodigdo. Setelah meminjam hasil ketikan stenografi tersebut, pada tahun 1959 Muhammad Yamin menerbitkan buku Naskah Persiapan Undang-Undang Dasar 1945 yang didasarkan oleh hasil ketikan stenografi itu, naskah asli hasil ketikan tersebut tidak pernah dikembalikan Muhammad Yamin kepada A.G. Pringgodigo sampai akhir hayatnya.

Naskah Persiapan Undang-Undang Dasar 1945 (selanjutnya disebut Naskah Persiapan) dianggap autentik karena merupakan kata demi kata (woordelijk) dari notulen sidang (notulistisch verslag) BPUPK ${ }^{7}$, sehingga sampai tahun 1992 dijadikan sumber utama penerbitan Sekretariat Negara. Buku terbitan Sekretariat Negara tersebut berjudul Risalah Sidang Badan Penyelidik Usahausaha Persiapan Kemerdekaan Indonesia-Panitia Persiapan Kemerdekaan Indonesia 28 Mei 1945-22 Agustus 1945 (selanjutnya disebut Risalah BPUPK 1). ${ }^{8}$ Pada tahun 1995 diterbitkan risalah sidang (selanjutnya disebut Risalah BPUPK 2) dengan tambahan dua sumber tertulis lainnya, yang oleh para penyunting Risalah BPUPK 2 disebut Koleksi Pringgodigdo dan Koleksi Yamin. Berdasarkan hal tersebut, sumber-sumber tertulis lengkap mengenai sidang BPUPK adalah Naskah Persiapan, Koleksi Yamin, dan Koleksi Pringgodigdo. Risalah BPUPK 1 dan Risalah BPUPK 2 secara garis besar tetap mendasarkan pada Naskah Persiapan dengan tambahan bahan Koleksi Pringgodigdo dan Koleksi Yamin disertai catatan kaki dari kedua koleksi tersebut sebagai perbandingan.

\footnotetext{
6 Risalah Sidang Badan Penyelidik Usaha-usaha Persiapan Kemerdekaan Indonesia, Sekretariat Negara, Jakarta, 1998, hlm., 691-692.

7 Nughroho Notosutanto, Proses Perumusan Pancasila Dasar Indonesia Merdeka, Balai Pustaka, Jakarta, 1981, hlm., 18.

8 Risalah Sidang Badan Penyelidik Usaha-usaha Persiapan Kemerdekaan Indonesia, Sekretariat Negara, Jakarta, 1995, xxviii-xxix.
} 
Naskah Persiapan dengan Koleksi Pringgodigdo dan Koleksi Muhammad Yamin memiliki persamaan serta perbedaan. ${ }^{9}$ Jika terdapat perbedaan Naskah Persiapan dengan Koleksi Pringgodigdo dan Koleksi Muhammad Yamin, maka Risalah BPUPK 1 dan Risalah BPUPK 2 yang diterbitkan Sekretariat Negara tidak dapat dijadikan rujukan karena sumber yang dijadikan dasar oleh Sekretariat Negara berbeda dengan sumber utamanya. Maka permasalahan yang muncul adalah, bagaimana autentisitas Naskah Persiapan, Koleksi Pringgodigdo dan Koleksi Yamin sebagai sumber tertulis sejarah perumusan istilah Pancasila pada masa sidang BPUPK 29 Mei-1 Juni 1945?

Penelitian hukum ini dilakukan menggunakan pendekatan historis (historical approach) ${ }^{10}$, yaitu pendekatan dalam kerangka pelacakan sejarah, dalam hal ini untuk mengetahui latar belakang munculnya istilah Pancasila sebagai dasar Indonesia dalam masa sidang pertama BPUPK.

\section{Pembahasan}

Notulen dan stenogram sidang BPUPK diketik untuk kemudian dijilid sebagai laporan kepada pihak Jepang dikumpulkan oleh A.G. Pringgodigdo selaku Wakil Ketua Tata Usaha BPUPK. Kepala Tata Usaha dari BPUPK adalah Raden Panji Soeroso yang berdomisili di kota Magelang. Berdasarkan domisili yang jauh dari Jakarta tersebut, maka urusan tata usaha sehari-hari dipegang oleh Wakil Kepala Tata Usaha, dalam hal ini adalah A.G. Pringgodigdo. Pihak Jepang mempercayakan kepada A.G. Pringgodigdo karena namanya tertera sebagai sekretaris Komisi Visman, sebuah komisi yang dibentuk untuk mencermati perkembangan ketatanegaraan di Hindia-Belanda. ${ }^{11}$

Formulasi Pancasila dalam masa sidang pertama BPUPK tercantum dalam beberapa sumber tertulis, baik berupa dokumen dan buku. Sumber tertulis pertama adalah laporan notulen dan stenogram dalam bundel Koleksi Yamin. Laporan stenogram yang sudah diketik tersebut mengingat sangat penting untuk

\footnotetext{
9 Id., hlm., XV

10 Peter Mahmud Marzuki, Penelitian Hukum, Kencana Prenada Media, Jakarta, 2009, hlm., 129.

11 A. G. Pringgodigdo, Perjuangan Bangsa Indonesia Menegakkan Pancasila Dalam Masa Penjajahan/Pendudukan Jepang, 1981, hlm., 122-123.
} 
segera dikirimkan kepada pihak Jepang di Tokyo, setelah dilakukan pengetikan, tidak lagi diperiksa. Menurut A.G. Pringgodigdo, ada 4 jilid laporan stenogram, dua jilid diserahkan kepada Jepang dan sisanya disimpan sendiri di kantor dan rumahnya. ${ }^{12}$ Laporan yang diarsipkan A.G. Pringgodigdo dikenal dengan nama Koleksi Yamin dikarenakan laporan inilah yang dipinjam oleh Muhammad Yamin sebagai sumber menyusun Naskah Persiapan dan tidak pernah dikembalikan, kemudian oleh pemerintah Orde Baru dinyatakan hilang. Koleksi Yamin ditemukan kembali di Puri Mangkunegaran, Surakarta. Saat itu B.R.A Satuti istri dari Rahadian Yamin yang merupakan putera Muhammad Yamin meminta karyawan Arsip Nasional Republik Indonesia (selanjutnya disebut ANRI) untuk merapihkan perpustakaan Mangkunegoro. Koleksi Yamin dianggap telah hilang seiring dengan meninggalnya Muhammad Yamin. Setelah karyawan ANRI menemukan Koleksi Yamin di perpustakaan tersebut, maka dibawa untuk disimpan di gedung ANRI Jakarta. ${ }^{13}$

Sumber tertulis kedua setelah Koleksi Yamin adalah Koleksi Pringgodigdo. Koleksi tersebut awalnya berada di ibu kota Republik Indonesia Yogyakarta, saat terjadi agresi militer II Belanda, menurut A.B. Kusuma dan R.E. Elson koleksi tersebut disita lalu di bawa ke negeri Belanda. ${ }^{14}$ Menurut M.J. Karabinos, saat pasukan Belanda menyerbu Yogyakarta pada tahun 1948, ratusan dokumen tentang Republik Indonesia selain Koleksi Pringgodigdo juga disita oleh Belanda, termasuk di dalamnya dokumen pribadi milik Mohammad Hatta. ${ }^{15}$ Dokumendokumen tersebut sekarang sudah dikembalikan kepada ANRI dan dinamai dengan nama "Djodgja Documenten”. Koleksi Pringgodigdo awalnya disimpan di Algemeen Rijksarchief kemudian disimpan oleh Nationaal Archief Nederland. ${ }^{16}$

\footnotetext{
12 Id., hlm., 133.

13 Supra no. 3, hlm., 3.

14 http://www.jstor.org/stable/41288761?origin=JSTOR-pdf, diakses tanggal 25 Januari 2017

15 https://openaccess.leidenuniv.nl/bitstream/1887/33293/9/03.pdf, diakses tanggal 25 Januari 2017.

16 Peneliti perlu mengucapkan terima kasih sebesar-besarnya kepada Professor (Em) R.E. Elson dari University of Queensland Brisbane yang telah memberikan salinan Algemene Secretarie En De Daarbij Gedepoonerde Archieven (1942-1950) yang memuat Archivalia van Raden Mas mr A.G. Pringgodigdo, destijds Secretaris van Staat van de Republiek Indonesië No. 5645-5647 milik Arsip Nasional Belanda.
} 
Menurut catatan dari Nationaal Archief Nederland, Koleksi Pringgodigdo telah dikembalikan kepada ANRI pada tahun 1987. Koleksi Pringgodigdo secara lengkap bernama Archivalia van R.M.MR. Abdul Gaffar Pringgodigdo, Secretaris van Staat van de Republiek Indonesie 1944-1945. Dahulu Koleksi Pringgodigdo dianggap sebagai koleksi milik adik A.G. Pringgodigdo, yaitu A.K. Pringgodigdo. Koleksi Pringgodigdo memuat:

\begin{tabular}{|c|c|c|}
\hline Nomor & Judul & Keterangan \\
\hline 5641 & $\begin{array}{l}\text { Keputusan Jepang berkenaan dengan tugas Dewan Sanyo dan } \\
\text { kewenangan pemerintah Indonesia, khususnya pemerintahan di } \\
\text { tingkat Kecamatan. Stensil. Tanpa tanggal. Desember } 1944\end{array}$ & 1 jilid \\
\hline 5642 & Notulensi rapat-rapat dari Dewan Sanyo Desember 1944 & 1 jilid \\
\hline 5643 & $\begin{array}{l}\text { Laporan, catatan dan dokumen lain berkenaan dengan pekerjaan } \\
\text { Dewan Sanyo di bidang penyediaan dan distribusi pangan serta } \\
\text { pemanfaatan lahan Desember } 1944 \text { - Pebruari } 1945\end{array}$ & 1 jilid \\
\hline 5644 & $\begin{array}{l}\text { Konsep notulensi rapat Dewan Sanyo untuk membicarakan hari- } \\
\text { hari raya dan libur, Pebruari } 1945\end{array}$ & 1 jilid \\
\hline 5645 & $\begin{array}{l}\text { Laporan rapat, notulensi, dan catatan perihal rapat-rapat Dokuritu } \\
\text { Zyunbi Tyosa Kai (Badan untuk Menjelidiki Usaha-Usaha Persiapan } \\
\text { Kemerdekaan) dan Panitia Persiapan Kemerdekaan Indonesia yang } \\
\text { muncul darinya. Mei-Agustus } 1945 .\end{array}$ & 1 jilid \\
\hline 5646 & $\begin{array}{l}\text { Dokumen tentang usulan UUD Indonesia, pertahanan Negara, } \\
\text { keuangan Negara dan ekonomi. Tanpa tanggal (medio 1945) }\end{array}$ & 1 jilid \\
\hline 5647 & $\begin{array}{l}\text { Indonesia merdeka selekas-lekasnya, manifesto sebagaimana } \\
\text { dinyatakan oleh anggota Dokuritu Zyunbi Tyosa Kai. Dua versi } \\
\text { dengan duplikat Tanpa tanggal (1945) }\end{array}$ & 1 jilid \\
\hline 5648 & $\begin{array}{l}\text { Nota perihal kedudukan Islam dalam Negara Indonesia merdeka. } \\
\text { Tanpa tanggal (1945) }\end{array}$ & 1 jilid \\
\hline 5649 & $\begin{array}{l}\text { Struktur Organisasi dan Tata Kerja untuk pemerintah Indonesia } \\
\text { menurut usulan Gerakan Angkatan Muda; dengan duplikat. Tanpa } \\
\text { tanggal (1945) }\end{array}$ & 2 lembar \\
\hline 5650 & $\begin{array}{l}33 \text { Fatsal Gerakan Hidoep Baroe; memuat pedoman hidup } \\
\text { sebagaimana diajukan oleh Gerakan Hidup Baru tersebut. Tanpa } \\
\text { tanggal (1945) }\end{array}$ & 1 lembar \\
\hline 5651 & $\begin{array}{l}\text { Pengumuman resmi dan publikasi diterbitkan oleh Republik } \\
\text { Indonesia dan organisasi kepemerintahan di bawahnya. Stensil. } \\
\text { September-Oktober } 1945 \text {. }\end{array}$ & 1 jilid \\
\hline 5652 & $\begin{array}{l}\text { Mosi, pernyataan, telegram dan surat-surat yang dibuat oleh organ- } \\
\text { organ pemerintahan, perkumpulan dan orang-perorang yang } \\
\text { disampaikan pada Presiden Soekarno, Wakil Presiden Hatta dan } \\
\text { Sekretariat Negara September-Oktober } 1945\end{array}$ & 1 pak \\
\hline 5653 & $\begin{array}{l}\text { Laporan dengan lampiran perihal penyediaan tenaga listrik di } \\
\text { Banyumas, dibuat oleh Djawatan Listrik Daerah Banjumas- } \\
\text { Purwokerto September 1945. }\end{array}$ & 1 jilid \\
\hline 5654 & $\begin{array}{l}\text { Laporan dengan lampiran yang dibuat Badan Penolong Keluarga } \\
\text { Korban Perang perihal tugas-tugas badan ini serta pelaksanaan } \\
\text { tugas-tugas tersebut serta laporan kerja dari Badan Keamanan } \\
\text { Rakjat yang berada di bawahnya. Oktober } 1945 \text {. Badan Penolong } \\
\text { Keluarga Korban Perang dan Badan Keamanan Rakjat }\end{array}$ & 1 jilid \\
\hline
\end{tabular}




\begin{tabular}{cll}
\hline 5655 & $\begin{array}{l}\text { Laporan tentang kejadian di Jakarta Raya dibuat oleh Kepala Polisi } \\
\text { setempat; Oktober 1945. }\end{array}$ & 1 jilid \\
\hline 5656 & $\begin{array}{l}\text { Keadaan tanaman di Jawa pada 1945; laporan tentang situasi } \\
\text { pertanian di Jawa dengan beberapa duplikat. Oktober 1945 }\end{array}$ & 1 jilid \\
\hline$\ldots$ & Beberapa catatan atau dokumen lepas memuat kuitansi, amplop & 1 jilid \\
& lepas, tanda terima (tidak disalin) Oktober 1945 dan tanpa tanggal. & \\
& Di simpan di Arsip Nasional di Jakarta; tidak ditemukan atau \\
& tersimpan fotokopinya di Arsip Nasional Belanda \\
\hline
\end{tabular}

Inventaris Koleksi Pringgodigdo nomor 5645 s.d. 5647 berhubungan dengan perumusan Undang-Undang Dasar 1945 yang di dalamnya terdapat pembahasan dasar Indonesia merdeka. Eksistensi dari Koleksi Pringgodigdo sebelum dikembalikan kepada ANRI, secara tersirat pernah disinggung oleh J.C.T Simorangkir dalam disertasinya yang dibukukan pada tahun 1984. Menurut J.C.T Simorangkir, ia menemukan dokumen dengan deskripsi sebagai berikut:

Dari bahan yang penulis jumpai di Algemeen Rijksarchief Algemene Secreatarie I Kist XXV nr. 26 s'Gravenhage Negeri Belanda dalam susunan upacara pembukaannya ditulis "Badan Oentoek Menyelidiki Oesaha-oesaha Oentoek Persiapan Kemerdekaan". Sedang pada naskah nasihat Gunseikan penulis jumpai istilah "Badan Oentoek menjelidiki oesaha-oesaha Persiapan Kemerdekaan...Dalam penelitian Penulis di luar Negeri, maka ternyata di Algemeen Rijksarchief di s'Gravenhage Negeri Belanda, terdapat bahan yang ditulis tangan berbunyi: "Ketua membentuk panitia kecil perancang Undang-undang Dasar terdiri atas Soepomo, Wongsonagoro, Soebardjo, Maramis, Singgih, Salim, Soekiman, Iin, Ketua Soepomo, Iin. Kewajiban Panitia Kecil: merancang Undang-undang Dasar, dengan memperhatikan pendapat-pendapat yang telah dimajukan di Rapat Panitia Perancang Undang-undang Dasar. ${ }^{17}$

Berdasarkan keterangan J.C.T Simorangkir saat melakukan pemeriksaan dokumen untuk disertasinya di Belanda, ditemukan dokumen yang tertulis Badan Oentoek Menjelidiki Oesaha-oesaha Persiapan Kemerdekaan (terjemahan untuk Dokuritu Zyunbi Tyo Sakai) dan dokumen tersebut merupakan tulisan tangan. J.C.T Simorangkir tidak dapat melakukan identifikasi penulis dokumen, hanya menduga ditulis oleh sekretaris atau petugas BPUPK, selain itu tidak terdapat keterangan nama dokumen, hanya menyebutkan nomor dan tempat dokumen disimpan.

\footnotetext{
17 J.C.T Simorangkir, Penetapan UUD Dilihat dari Segi Ilmu Hukum Tata Negara Indonesia, Gunung Agung, Jakarta, hlm., 9 dan 13.
} 
Tidak dijumpai juga apakah dokumen tersebut merupakan notulen sidang atau stenogram. Di dalam yang ditemukan olehnya memuat tiga hal, yaitu:

1. BPUPK melaksanakan rapat besar (rapat pleno);

2. Panitia hukum dasar dengan Ir. Soekarno sebagai ketua, disebut dalam dokumen tersebut sebagai Panitia Perancang Undang-Undang Dasar;

3. Panitia Kecil dengan Prof. Soepomo sebagai ketua, disebut sebagai Panitia Kecil Perancang Undang-undang Dasar. ${ }^{18}$

Dokumen tersebut baru diketahui sebagai stenografi sidang BPUPK sekembalinya J.C.T Simorangkir ke Indonesia dan mewawancarai Moh. Hassan selaku anggota PPKI. Kepadanya diberikan salinan stenografi sidang pembahasan Undang-Undang Dasar. ${ }^{19}$ Kembali kepada Koleksi Yamin, selain dipinjamkan kepada Muhammad Yamin, pada tahun 1957, Pratignyo dari Departemen Luar Negeri pernah meminta salinan kepada A.G. Pringgodigdo untuk diperbanyak dalam bentuk stensil dan telah diberikan seadanya. ${ }^{20}$ Menurut A.B. Kusuma, ada perbedaan risalah sidang yang diterbitkan Departemen Luar Negeri, yaitu pada beberapa bagian pada pidato Muhammad Yamin diberi tanda khusus berupa kotak untuk menandakan bahwa bagian tersebut tidak dapat disebut otentik. ${ }^{21}$

Sumber tertulis ketiga adalah Naskah Persiapan yang ditulis oleh Muhamamd Yamin. Naskah Persiapan diterbitkan oleh Yayasan Prapantja pada tahun 1959 dan diberi Kata Pengantar oleh Presiden Soekarno. Naskah Persiapan menjadi sumber utama penerbitan Risalah Sidang BPUPK 1 dan BPUPK 2 oleh Sekretariat Negara.

Koleksi Yamin, Koleksi Pringgodigdo dan Naskah Persiapan pada prinsipnya sama-sama memuat pidato mengenai perumusan dasar negara merdeka pada masa sidang pertama BPUPK tanggal 29 Mei hingga 1 Juni 1945. Perbedaan di antara ketiganya adalah mengenai pencantuman siapa dan isi pidato pada tanggal 29 Mei hingga 1 Juni 1945. Dalam Naskah Persiapan, Risalah BPUPK 1, dan Risalah BPUPK 2 pada tanggal 29 Mei 1945 hanya ditampilkan pidato dari

\footnotetext{
18 Supra no. 17., hlm., 14

${ }^{19}$ Id., hlm., 23

${ }^{20}$ Moh. Hatta, Ahmad Soebardjo, et.al, Uraian Pancasila, Mutiara, Jakarta, 1984, hlm., 79.

${ }^{21}$ Supra no. 3, hlm., 6
} 
Muhammad Yamin, pada tanggal 31 Mei 1945 hanya pidato Soepomo dan pada 1 Juni 1945 pidato Soekarno. Naskah Persiapan, Risalah BPUPK 1 dan Risalah BPUPK 2 tidak menjelaskan alasan mengapa hanya mencantumkan tiga orang saja. Ketiga pidato tersebut tidak mencantumkan asal-usul pertanyaan yang menyebabkan ketiga orang itu berpidato. Informasi mengapa muncul pidato dari ketiga orang tersebut dalam waktu yang berbeda dapat ditemukan dalam wasiat Mohammad Hatta kepada Guntur Soekarnoputra sebagai berikut:

Dekat pada akhir bulan Mei 1945 dr. Radjiman, ketua Panitia Penyelidik Usaha-usaha Kemerdekaan Indonesia, membuka sidang Panitia itu dengan mengemukakan pertanyaan kepada rapat: "Negara Indonesia Merdeka yang akan kita bangun itu, apa dasarnya?. Kebanyakan anggota tidak mau menjawab pertanyaan itu, karena takut pertanyaan itu akan menimbulkan persoalan filosofi yang akan berpanjang-panjang"22

Berdasarkan keterangan Mohammad Hatta, diperoleh informasi bahwa pada sidang perdana 29 Mei 1945, Radjiman Wediodiningrat selaku ketua BPUPK bertanya landasan filsafati dasar negara Indonesia merdeka kepada seluruh peserta sidang. Pertanyaan dari Radjiman Wediodiningrat tersebut ditanggapi oleh sebagian anggota BPUPK. Ada tiga tokoh yang dikenal mencoba menjawab pertanyaan itu, mereka adalah Muhammad Yamin, Soepomo, dan Soekarno. Di dalam Naskah Persiapan ${ }^{23}$, Risalah BPUPK 1, dan Risalah BPUPK $2{ }^{24}$ pidato dari Muhammad Yamin berjudul "Azas dan Dasar Negara Kebangsaan Republik Indonesia" mengandung inti lima hal, yaitu:

1. Peri Kebangsaan;

2. Peri Kemanusiaan;

3. Peri Ketuhanan;

4. Peri Kerakyatan;

5. Kesejahteraan Rakyat.

\footnotetext{
22 Supra no. 20, hlm., 101

${ }^{23}$ Muhammad Yamin, Naskah Persiapan Undang-undang Dasar 1945, Prapantja, Djakarta, 1959, hlm., 87-88.

${ }^{24}$ Supra no. 8, hlm., 8-9
} 
Hal tersebut juga diperkuat oleh Nugroho Notosutanto yang berpegangan kepada Naskah Persiapan. ${ }^{25}$ Pada Risalah BPUPK 2, pidato Muhammad Yamin diberi catatan kaki bahwa pidato tersebut tidak terdapat di dalam Koleksi Yamin maupun Koleksi Pringgodigdo. ${ }^{26}$ Pada penutup pidato 29 Mei 1945 dalam Naskah Persiapan, Risalah BPUPK 1, dan Risalah BPUPK 2 terdapat keterangan sebagai berikut:

Habislah pembicaraan tentang azas kemanusiaan, kebangsaan, kesejahteraan dan dasar yang tiga, yang diberi kerakhmatan Tuhan, yang semuanya akan menjadi tiang negara keselamatan yang akan dibentuk. Dengan ini saya mempersembahkan kepada sidang sebagai lampiran suatu rancangan sementara berisi perumusan Undang-Undang Dasar Republik Indonesia. Dua hari yang lampau tuan Ketua memberi kesempatan kepada kita sekalian juga boleh mengeluarkan perasaan ${ }^{27}$

Berdasarkan keterangan Risalah BPUPK 2 tersebut, pada 29 Mei 1945, Muhammad Yamin berpidato tentang dasar Indonesia merdeka, melampirkan rancangan Undang-Undang Dasar Sementara, dan ikut terbawa emosional menyatakan perasaan mengenai kemerdekaan Indonesia dua hari sebelum tanggal 29 Mei 1945. Catatan kaki Risalah BPUPK 2 tentang tidak ditemukannya pidato Muhammad Yamin pada Koleksi Muhammad Yamin dan Koleksi Pringgodigdo menimbulkan permasalahan, jika tidak terdapat pada kedua dokumen tersebut, maka pidato yang dicantumkan Muhammad Yamin pada Naskah Persiapan, Risalah BPUPK 1 dan Risalah BPUPK 2 tidak jelas asal-usulnya. Notulen sidang tanggal 29 Mei 1945 dari Koleksi Pringgodigdo memuat pidato Muhammad Yamin sebagai berikut: 28

25 Supra no. 7, hlm., 53

${ }^{26}$ Supra no. 8, hlm., 8

27 Id., hlm., 28

28 Risalah Sidang 29 Mei 1945 ditulis sebagaimana terdapat dalam Archivalia van Raden Mas A.G. Pringgodigdo dan membandingkannya dengan buku Lahirnya Undang-Undang Dasar 1945 karya A.B. Kusuma. 
$\underline{\text { Muh. Yamin }}{ }^{29}$

\section{DOKURITU ZYUNBI TYOSA KAI}

Bahan djangan sadja ditjari di Djawa, tetapi di seloeoroeh Ind Borneo, Selebes, Maloekoe, Malaja, Soematra dan Soenda Ketjil.

Tiga oesaha jang haroes dilakoekan:

1. Mengoempoelkan bahan oentk. pemb neg

2. Menjoesoen oendang2 dasar negara

3. Mendjalankan isi hoekoem dasar neg. Ind

Ind. Merdeka, sekarang!

I. Etat nation=nationale staat=negara kebangsaan

Dasar kemerdekaan=kedaoelatan ke dalam dan kedaoelatan ke loear

Ked. kedalam $=$ memberi perlindoengan dan pengawasan pada poetra negeri

Ked. keluar=kesempatan loeas mengatoer pertalianja dengan negara lain

Boekan dominion, protectoraat, mandaat, Atlantic Charter

Toedjoean II dasar kemanusiaan

Kemerdekaan (internasionalisme)

dasar kedaoelatan rakjat

ataoe kedaoelatan negara

III. KeToehanan

Peradaban Ind mempoenjai

Toehan jang Maha Esa

IV. Dasar jang tiga

A. Permoesjawaratan (Qoeran)-moefakat (adat)

B. Perwakilan (adat)

C. Kebidjaksanaan (rasionalisme)

1. Negara Repoeblik Ind: I. Repoeblik, negara Kesatoean, faham unitarisme

II. Satoe kedaoelatan: jang didjoendjoeng oleh Kepala Negara, daerah, dan rakjat

III.Kepala Negara, pemerintah daerah dan pemerintah persekoetoean desa (nagari, marga, dll) dipilih setjara Timoer dalam permoesjawaratan jang disoesoen setjara rakjat. Pemerintahan Sjariah

IV.Permoesjawaratan, pemilihan, dan pembaroean pikiran mendjadi dasar pengangkatan dari sagala pemoetoesan oeroesan Negara

V. Nagari, desa dan sagala persekoetoean hukum adat jang diperbaroei dengan djalan rasionalisme dan pembaroean djaman, dijadikan kaki soesoenan negara sebagai bagian bawah

${ }^{29}$ Notulensi pidato tidak berjudul Muhammad Yamin pada tanggal 29 Mei 1945 terdiri atas 2 lembar. Pada lembar pertama hilang $1 / 3$ halaman, sebagaimana penulis dapatkan dari inventaris nomor 5645 dan 5646 National Archief Belanda. Hal ini karena keteledoran dari National Archief ketika menyalin dari notulen asli yang dikembalikan ke ANRI pada tahun 1987. 
VI. Pemerintah Poesat dibentoek disekeliling Kepala Negara terdjadi atas: a. doewa orang wakil kepala Negara

b. satoe kementerian sekeliling seorang Perdana Menteri

c. Poesat parlemen badan-badan perwakilan, jang terbagi atas balai Pertemoean dan Balai Perwakilan Rakjat

Muh. Yamin

$\underline{2}$

DOKURITU ZYUNBI TYOSA KAI

VII. Antara bagian atas dan bagian bawah dibentoek bagian tengah sebagai Pemerintah Daerah. Oentok pemerintah Oeroesan dalam, Pangreh Pradja sekarang mementingkan kekoeasaan kepada Negara Ind dan Pemerintah. Urusan dalam negeri bagi seluruh Ind disoesoen kembali

VIII. Pekerdjaan atas djalan desentralisasi atau dekonsentrasi jang tidak mengenal federalisme ataoe pepetjahan negara

IX. Ind Mendjadi anggota jang berkedaoelatan dalam permoesjawaratan bangsa2 ATR dan dalam persaoedaraan bangsa2 sedoenia Negara Rakjat Ind. Bukan negara golongan, negara angkatan ataoe negara bangsawan

2. Pembelaan: Perang jihad (agama)-perang keraman (adat) menyempurnakan teknik dan disiplin peperangan dan menjusun siasat perang (rasionalisme)

3. Boedi Negara (moral) Ind jang ketiga

a. Setia negara $=$ rasa kebaktian (Sjailendra-Sriwidjaja) I

b. Tenaga rakjat= kekuatan rakjat (Madjapahit-Gadjah Mada) II

c. Kemerdekaan= ingin merdeka (Ind Merdeka) III

V Kesedjahteraan Rakjat: Peroebahan besar tentang kesejahteraan jang mengenai kehidupan ekonomi dan sosial sehari-hari jang mengenai diri poetra negeri

a. Daerah Negara. Kemaoean angkata moeda Ind. Soematera Djawa, Malaja, Borneo, Selebes, Soenda Ketjil, Maloekoe, Papoea

b. Pendoedoek dan Poetera Negara. Sebeloem hari pelantikan Negara diadakan ketentoean tentang kedoedoekan golongan Peranakan Arab dan Tionghoa. Djalan memasoeki daerah kepoeteraan terboeka selama-lamanja ${ }^{30}$

c. Bentuk Negara: berkat bantoean Bala D.N. dan berkat kesoenggoehan perdjoangan rakjat Ind ditakdirkan oleh Toehan kita naik dari kedoedoekan djadjahan mendjadi rakjat Negara Merdeka

Sjair Repoeblik Indonesia ${ }^{31}$

30 Di dalam buku A.B. Kusuma yang berujudul “Lahirnya Undang-Undang Dasar 1945” tertulis

"seluas-luasnya"

31 A.B. Kusuma, supra no.4, hlm., 99 tertulis "Syair Indonesia Merdeka” 
Berdasarkan notulen dari Koleksi Pringgodigdo, tidak ditemukan lima jenis dasar Indonesia merdeka sebagaimana dinyatakan oleh Muhammad Yamin dalam Naskah Persiapan. Isi notulen dalam Koleksi Pringgodigdo hanya memberikan informasi tentang gambaran idealnya negara yang sudah merdeka dengan tiga dasar. Bila mengikuti alur Muhammad Yamin dalam bukunya Naskah Persiapan dan Nugroho Notosutanto bahwa pada tanggal tersebut Muhammad Yamin menjabarkan dasar Indonesia ketika merdeka, maka hanya tiga dasar saja, yaitu permusyawaratan, perwakilan, dan kebijaksaan. Sementara kebangsaan, kemanusiaan, dan kesejahteraan adalah asas. Tetapi asumsi tersebut juga tidak dapat dipertanggungjawabkan karena Panji Soeroso selaku Fuku Kaityo (Wakil Ketua) menegur ${ }^{32}$ Muhammad Yamin sebanyak empat kali karena dianggap tidak menjawab pertanyaan mengenai landasan filsafati dasar Indonesia merdeka yang diajukan oleh Radjiman Wediodiningrat. Dengan kata lain pidato Muhammad Yamin yang panjang sebagaimana dimuat dalam Naskah Persiapan dan Risalah BPUPK 1 serta 2 tidak menyentuh substansi permasalahan yang diajukan. Pada akhir pidato Muhammad Yamin menyatakan telah mengeluarkan perasaan pada dua hari sebelum sidang perdana 29 Mei 1945. Menjadi tanda tanya besar terhadap klaim Muhammad Yamin dalam bukunya itu jika dia, oleh Radjiman Wedioningrat, diberi kesempatan mengeluarkan perasaannya dua hari sebelumnya, yang berarti pada tanggal 27 Mei 1945, padahal pada tanggal tersebut BPUPK belum mengadakan rapat dan diresmikan. Dengan demikian dapat disimpulkan pada tanggal 29 Mei 1945 Muhammad Yamin tidak mengajukan landasan filsafati dasar Indonesia merdeka yang berjumlah lima.

Koleksi Pringgodigdo memuat nama-nama anggota BPUPK yang berpidato pada tanggal 29 Mei 1945. Nama-nama anggota yang berpidato tetapi sengaja tidak dicantumkan bersama pidato mereka dalam Naskah Persiapan, Risalah BPUPK 1 dan Risalah BPUPK 2, yaitu: Margono, Sosrodiningrat, Soemitro, Wiranatakoesoema, Woerjaningrat, Soerjo, Soesanto, Soedirman, Dasaad, Rooseno, dan Aris, kecuali Margono yang naskah pidatonya belum ditemukan,

32 Supra no. 23, hlm., 99-105. 
pidato pada tanggal 29 Mei 1945 tersedia dalam bentuk notulen dan stenogram. ${ }^{33}$ Tanggal 30 Mei 1945, ada sembilan orang yang berpidato pada sidang BPUPK. Naskah Persiapan, Risalah BPUPK 1, dan Risalah BPUPK 2 tidak mencantumkan isi pidato dari 9 orang tersebut. Sembilan orang tersebut adalah: Hatta, H. Agoes Salim, Samsoedin, Wongsonagoro, Soerachman, Soewandi, A. Rachim, Soekiman, dan Soetardjo. ${ }^{34}$ Dalam Koleksi Pringgodigdo, pidato yang berhasil ditemukan adalah pidato dari Wongsonegoro dan A. Rachim Pratalykrama dalam bentuk notulen. Isi pidato kedua orang itu yang berhubungan dengan dasar Indonesia merdeka sebagai berikut:

\section{WONGSONAGORO}

Pembentukan negara baru dilakukan dengan 2 tingkatan atau 2 angsuran:

Penyusunan Pemerintahan luar biasa buat sementara waktu. Bersifat istimewa dan berkewajiban menyelesaikan peperangan ini

Dan berkewajiban mempersiapkan pemerintahan yang tetap. Harus menjalankan usaha mengurus kemajuan dan hasrat rakyat pada umumnya, baik tentang susunan dan corak negara, maupun tentang aturan dasar (grondwet), pun cara pemilihan wakil rakyat. Minta diberi aturan dasar Mancukuo, Tiongkok, Philipina sebagai contoh. Peradaban batin harus dipertinggi. Jangan mementingkan diri sendiri Mission Saccre mewajibkan kita turut menyusun kemakmuran bersama di Asia Timur Raya dan membantu menertibkan seluruh dunia dengan Hakko Ittiu. ${ }^{35}$

\section{PRATALYKRAMA}

Negara Indonesia: Kepala dipilih rakyat, punya Perdana Menteri dan Kabinet

Badan Perwakilan Rakyat: Majelis Luhur dan Majelis Rendah, yang anggotanya dipilih oleh rakyat

Keluar: Satu Negara di dalam: beberapa daerah pemerintahan dan kota-kota yang masing-masing otonomi dengan tunduk pada pimpinan Kepala Negara Indonesia

Pembelaan: milisi umum sebelumnya itu diadakan gemblengan bagi rakyat di juken-juken sebagai sekarang, buat menimbulkan semangat berkorban buat tanah air

Pendidikan: kewajiban belajar

33 Sama dengan catatan kaki nomor 31, beberapa notulensi hilang $1 / 3$ karena kesalahan penyalinan.

34 Supra no. 5, hlm.,119-120

35 Archivalia van Raden Mas mr Abdul Gaffar Pringgodigdo, destijds Secretaris van Staat van de Republiek Indonesië Nr. 5645-5647 
Perekonomian: ekonomi dalam arti seluas-luasnya perlu diperluas dan diperdalam dan disegala lapangan misalnya nasionalisasi dari perusahaan-perusahaan. Aturan-aturan hak tanah-tanah komunal dihapuskan, tanah erpacht...Dan opstal harus dikembalikan kepada rakyat via pemerintah

Dasar negara: persatuan rakyat sekokoh-kokohnya. Agama Islam 95\% dari penduduk beragama dan Kepala Negara harus seorang muslim. Islam sebagai Agama Negara dengan kemerdekaan seluas-luasnya bagi penduduk untuk memeluk agama yang bukan Islam

Permulaan pembangunan Negara harus minta bantuan kepada Dai Nippon berupa penasehat-penasehat dan lain-lain ${ }^{36}$

Berdasarkan 2 pidato tersebut, A. Rachim Pratalykrama yang dengan jelas berbicara mengenai dasar Indonesia merdeka, yaitu persatuan yang didasarkan atas rakyat yang kokoh. Selain itu juga diusulkan bahwa kepala negara harus beragama Islam, Islam sebagai agama negara, serta kebebasan menjalankan agama selain Islam sesuai yang diinginkannya. Pidato Hatta meskipun belum ditemukan, secara garis besar membahas mengenai pemisahan agama dan negara. Hatta sendiri tidak menjawab dengan jelas pertanyaan Radjiman Wediodiningrat. Dalam pidatonya dijelaskan konsep sekularisme dipraktikan di negara-negara Barat. Paus dianggap sebagai raja sekaligus pemuka agama, sehingga menimbulkan pertentangan terus-menerus. Dalam konteks Indonesia hal itu tidak dibenarkan karena agama dan negara saling mengisi. ${ }^{37}$

Sidang BPUPK tanggal 31 Mei 1945 terdapat 14 orang anggota yang berbicara, tidak hanya Soepomo saja yang berpidato hari itu. Mereka adalah: Abdul Kadir, Soepomo, Hendromartono, Muhammad Yamin, Sanoesi, Liem Koen Hian, Moenandar, Dahler, Soekarno, Ki Bagoes Hadikoesoemo38, Koesoema Atmaja, Oei Tjong Hauw, Parada Harahap, dan Boentaran. ${ }^{39}$ Selain pidato

\footnotetext{
${ }^{36}$ Id.

${ }^{37}$ Supra no. 7, hlm., 83.

38 Pidato Ki Bagoes Hadikoesoemo tidak terdapat dalam Koleksi Pringgodigdo, Koleksi Yamin, dan Naskah Persiapan. Pidato dalam "Risalah Sidang Badan Penyelidik Usaha-usaha Kemerdekaan Indonesia" edisi 1998 diambil dari arsip keluarga Ki Bagoes Hadikoesoemo yang diserahkan oleh puteranya yang bernama Kolonel (L) Basmal Hadikkoesoemo kepada Sekretariat Negara, sedangkan pidato di dalam buku "Lahirnya Undang-undang Dasar 1945" karya A.B. Kusuma diambil dari buku "Ki Bagus Hadikoesoemo" terbitan Departemen Pendidikan dan Kebudayaan tahun 1982.

${ }^{39}$ Supra no. 3, hlm., 121.
} 
Soepomo, notulen pidato yang sementara berhasil ditemukan adalah notulen pidato Abdul Kadir, Dahler, dan Liem Koen Hian. Pidato pada tanggal 31 Mei 1945 yang masyhur adalah pidato dari Soepomo, ia mencoba untuk menjawab pertanyaan dari Radjiman Wediodiningrat tentang dasar Indonesia merdeka. Menurut Nugroho Notosutanto ${ }^{40}$, pidato Soepomo pada hari itu berisi lima dasar Indonesia merdeka, yaitu:

1. Persatuan;

2. Kekeluargaan;

3. Keseimbangan lahir dan batin;

4. Musyawarah;

5. Keadilan rakyat.

Soepomo sendiri tidak pernah menyebut dalam pidatonya kelima hal itu sebagai dasar Indonesia merdeka atau bahkan menyebutnya dengan istilah Pancasila. Kelima hal tersebut barulah ditafsirkan dikemudian hari oleh Nugroho Notosutanto. ${ }^{41}$ Jika melihat pidato Soepomo seutuhnya ${ }^{42}$, maka konteks pidato Soepomo berbicara mengenai struktur sosial Indonesia yang ditopang oleh semangat persatuan hidup, semangat kekeluargaan, keseimbangan lahir batin masyarakat, yang senantiasa bermusyawarah dengan rakyatnya demi menyelenggarakan keinsyafan keadilan rakyat. Soepomo juga menyebutkan mengenai aliran pikiran (staatsidee) Indonesia nantinya, yaitu negara yang integralistik. ${ }^{43}$ Dalam hubungan antara agama dan negara, Soepomo sependapat dengan pidato Hatta pada tanggal 30 Mei 1945, yaitu mengenai pemisahan antara agama dan negara. Dengan kata lain, sependapat harus ada pemisahan antara urusan keagamaan dan urusan kenegaraan. ${ }^{44}$ Berdasarkan hal itu, maka pada tanggal 31 Mei 1945 Soepomo tidak menjelaskan dasar Indonesia merdeka yang berjumlah lima.

\footnotetext{
40 Supra no. 7, hlm., 53.

41 Id., hlm. 26

42 Supra no. 4, hlm. 35-36.

43 Supra no. 8., hlm., 36.

44 Id, hlm. 38-39
} 
Tanggal 1 Juni 1945, Soekarno diberikan kesempatan untuk berpidato mengenai dasar Indonesia merdeka. Pidato tersebut dimulai dengan koreksi Soekarno atas pidato-pidato para anggota BPUPK yang selama tiga hari berturutturut tidak menjawab pertanyaan dari Radjiman Wediodiningrat. Menurut Soekarno, yang ditanyakan oleh Radjiman Wediodiningrat sebenarnya adalah dasar Indonesia merdeka dalam artian philosofische grondslag.

Maaf, beriboe maaf! Banjak anggota telah berpidato, dan dalam pidato mereka itoe dioetarakan hal-hal jang sebenarnja boekan permintaan padoeka toean Ketoea jang mulia, jaitoe boekan dasarnja Indonesia Merdeka. Menoeoroet anggapan saja, jang diminta oleh Padoeka toean Ketoea jang moelia ialah, dalam bahasa Belanda: "Philosofische grondslag" daripada Indonesia Merdeka. Philosofische grondslag itoelah poendamen, filsafat, pikiran-jang-sedalam-dalamnja, djiwa, hasrat-jang sedalam-dalamnja oentoek diatasnja didirikan gedoeng Indonesia Merdeka jang kekal dan abadi ${ }^{45}$.

Pidato Soekarno pada tanggal 1 Juni 1945 tentang dasar Indonesia merdeka yang dikenal dengan sebutan Pancasila, terdiri atas lima hal: 46

1. Kebangsaan Indonesia

2. Internasionalisme-atau peri-kemanoesiaan

3. Moefakat-atau demokrasi

4. Kesedjahteraan sosial

5. Ketoehanan

Berdasarkan hal tersebut, baru pada tanggal 1 Juni 1945 ada usulan lima dasar Indonesia merdeka yang diperkenalkan kepada sidang BPUPK dengan nama Pancasila dan juga menjawab pertanyaan Radjiman Wediodiningrat. Pidato Soekarno pada tanggal 1 Juni 1945 tersebut kemudian disebarluaskan dan diterbitkan pertama kali oleh Oesaha Penerbitan Goentoer pada tahun 1947 di Jogjakarta. Dalam penerbitan tersebut Radjiman Wediodiningrat memberikan kata pengantar dan menjelaskan pula sumber naskah:

"Lahirnja Pantja Sila" ini adalah boeah "stenografisch verslag" dari pidato Boeng Karno jang dioetjapkan dengan tidak tertoelis dahoeloe (voor de vuist) dalam sidang jang pertama pada tanggal 1 Djoeni 1945

\footnotetext{
45 Soekarno, Lahirnja Pantja Sila: Boeng Karno menggembleng dasar-dasar Indonesia merdeka, Oesaha Penerbitan Goentoer, Jogjakarta, 1947, hlm., 1.

46 Id., hlm. 33
} 
ketika sidang membitjarakan "Dasar (beginsel) Negara kita”...Bila kita peladjari dan selidiki soenggoh-soenggoeh "Lahirnja Pantja Sila” ini, akan ternjata bahwa ini adalah soeatoe Demokratische Beginsel, soeatoe Beginsel jang mendjadi Dasar Negara kita, jang mendjadi Rechtsideologie Negara kita.

Radjiman Wediodiningrat selain menjelaskan mengenai sumber naskah penerbitan, juga mengakui bahwa pidato Soekarno 1 Juni 1945 adalah pidato yang bisa menjawab pertanyaan dasar Indonesia merdeka yang diajukannya pada sidang tanggal 29 Mei 1945. Dasar Indonesia merdeka yang dimaksudkan oleh Radjiman Wediodiningrat tidak lain adalah dasar negara Indonesia. Dengan disebutnya Pancasila dalam kalimat "beginsel yang menjadi dasar negara kita" dan rechtsideologie (ideologi hukum) menjadi jelas bahwa pidato 1 Juni 1945 merupakan satu-satunya pidato yang menyebut secara jelas istilah Pancasila sebagai dasar kelak Indonesia merdeka. Nugroho Notosutanto dengan mendasarkan pada tulisan dari A.G. Pringgodigdo, berusaha mengatakan bahwa selain Soekarno, Muhammad Yamin dan Soepomo dapat dikatakan sebagai penggali Pancasila. ${ }^{47}$ Tulisan dari A.G. Pringgodigdo tersebut berasal dari stensil yang berjudul "Sekitar Pancasila" yang diterbitkan tahun 1970 oleh Kodam VIII Brawijaya. Pada tahun 1975 A.G. Pringgodigdo menjadi anggota Panitia Lima yang bertugas menyusun uraian tentang lima sila dari Pancasila dan pada tahun 1977 hasil pertemuan Panitia Lima diterbitkan dengan judul Uraian Pancasila. Dalam uraian tentang sejarah lahirnya Pancasila hanya disebutkan nama Soekarno saja yang mengucapkan istilah tersebut. ${ }^{48}$ Dengan demikian menyebut Muhammad Yamin dan Soepomo sebagai pihak yang turut mengemukakan istilah Pancasila yang didasarkan atas tulisan A.G. Pringgodigdo tidak tepat, karena A.G. Pringgodigdo sendiri "mengubah" pendiriannya dengan ikut serta menandatangi hasil Panitia Lima yang didalamnya secara jelas menyebutkan Soekarno sebagai orang yang pertama mengemukakan istilah Pancasila. Alasan lainnya adalah pidato Muhammad Yamin dan Soepomo tidak pernah sama sekali menyebut istilah Pancasila atau sekedar membagi dasar menjadi lima.

47 Supra no. 7, hlm., 67.

48 Supra no. 20, hlm., 25. 
Pidato 1 Juni 1945 merupakan pidato yang pertama diterbitkan mendahului penerbitan risalah sidang. Antara Naskah Persiapan, Risalah BPUPK 1, dan Risalah BPUPK dengan terbitan Oesaha Penerbitan Goentoer dan Penerbitan Chusus Departemen Penerangan memiliki perbedaan terkait pidato Soekarno pada tanggal 1 Juni 1945. Risalah BPUPK 1 dan Risalah BPUPK 2 merupakan produk salin tempel dan sunting ejaan dari Naskah Persiapan karya Muhammad Yamin sehingga substansi selain kesalahan ejaan sudah pasti terbawa. Sementara itu Penerbitan Chusus dari Departemen Penerangan mendasarkan atas terbitan dari Oesaha Penerbitan Goentoer, sehingga substansi selain ejaan yang diperbarui akan sama pula. Hal ini sebagaimana diakui oleh Departemen Penerangan selaku penerbit pidato "Lahirnja Pantja Sila":

Pidato Bung Karno tersebut kemudian dinamakan "Lahirnya PantjaSila" jang pernah dibukukan oleh Penerbit "Oesaha Penerbitan Goentoer" tahun 1947 di Jogjakarta. Isi penerbitan tersebut mendjadi bahan-utama bagi Penerbitan Chusus Deppen sekarang dengan beberapa perobahan kata pengantarnja dan edjaannja disesuaikan dengan edjaan jang baru.

Hal yang perlu diperhatikan Naskah Persiapan, Risalah BPUPK 1, dan Risalah BPUPK 2 tidak ada kata pengantar dari Radjiman Wediodiningrat. Konsekuensinya manakala ada perbedaan karena kesalahan ketik maupun substansi antara stenogram dengan naskah buku tidak akan diketahui. Peneliti berpendapat, sebelum diterbitkan, rancangannya sudah dibaca terlebih dulu oleh Radjiman Wediodiningrat, lalu setelah menurutnya tidak terdapat kesalahan substansial, barulah buku diterbitkan. Tidak mungkin Radjiman Wediodiningrat gegabah menyetujui penerbitan, apalagi terdapat kata pengantar atas nama dirinya ketika menjabat ketua BPUPK, tanpa memeriksanya terlebih dulu. Hal itu diperkuat dengan pernyataan Radjiman bahwa memang substansinya sama. ${ }^{49}$ Artinya Radjiman Wediodiningrat tahu persis pidato lisan 1 Juni 1945 adalah pidato yang mencantumkan istilah Pancasila.

${ }^{49}$ Supra no. 45 , hlm. 3-4. 
Naskah Persiapan memuat pidato 1 Juni 1945 mengenai Pancasila pada prinsip Ketuhanan sebagai berikut:

Prinsip $\mathrm{K}$ e t $\mathrm{u} \mathrm{h}$ a $\mathrm{n}$ a $\mathrm{n}$ ! Bukan sadja bangsa Indonesia berTuhan, tetapi masing-masing orang Indonesia hendaknja ber-Tuhan. Tuhanja sendiri. Jang Kristen menjembah Tuhan menurut petunjuk Isa al Masih, jang belum berTuhan menurut petundjuk Nabi Muhammad s.a.w, orang Buddha mendjalankan ibadatnja menurut kitab-kitab jang ada padanja ${ }^{50}$

Hal yang sama terdapat pada Risalah BPUPK 1 dan Risalah BPUPK 2:

Prinsip $\mathrm{K}$ e t $\mathrm{u} \mathrm{h}$ a $\mathrm{n}$ a $\mathrm{n}$ ! Bukan saja bangsa Indonesia ber-Tuhan, tetapi masing-masing orang Indonesia hendaknya ber-Tuhan. Tuhannya sendiri. Yang Kristen menyembah menurut petunjuk Isa al Masih, yang belum ber-Tuhan menurut petunjuk Nabi Muhammad saw, orang Buddha menjalankan ibadatnya menurut kitab-kitab yang ada padanya. ${ }^{51}$

Kalimat "yang belum ber-Tuhan menurut petunjuk Nabi Muhammad" tidak tepat. Selain secara struktur bahasa ganjil, berdasarkan konteks pembicaraan tersebut adalah mengenai ber-Tuhan sesuai dengan agama dan kepercayaannya masing. Pada teks terbitan "Oesaha Penebitan Goentoer" tertulis sebagai berikut:

Prinsip Ketoehanan! Boekan sadja bangsa Indonesia bertoehan, tetapi masing-masing orang Indonesia hendaknja bertoehan Toehannja sendiri. Jang Kristen menjembah Toehan menoeroet petoendjok Isa al Masih, jang Islam bertoehan menoeroet petoendjoek Nabi Moehamad s.a.w., orang Boeddha mendjalankan ibadatnja menoeroet kitab-kitab jang ada padanja. ${ }^{52}$

Naskah Persiapan, Risalah BPUPK 1 dan Risalah BPUPK 2 tertulis "yang belum ber-Tuhan" sedangkan dalam terbitan Oesaha Penerbitan Goentoer dan Penerbitan Chussus Departemen Penerangan tertulis "yang beragama Islam". Perbedaan tersebut tidak dapat dipandang sekedar salah ketik, tetapi mengubah makna. Hal ini menunjukkan bahwa Naskah Persiapan diragukan keautentikannya sehingga dapat dikesampingkan sebagai rujukan.

50 Supra no. 23, hlm. 77.

51 Supra no. 8, hlm. 80.

52 Supra no. 45 , hlm. 34 . 
Koleksi Yamin dan Koleksi Pringgodigdo yang berisi stenogram dan notulen tidak mencantumkan kalimat "yang belum ber-Tuhan", sehingga diketahui bahwa Naskah Persiapan tidak mengutip stenogram dan notulen kata demi kata darinya. Sehingga yang dapat dikategorikan sebagai sumber autentik hanya Koleksi Yamin dan Koleksi Pringgodigdo.

Berdasarkan hal tersebut, Naskah Persiapan yang dijadikan sumber Risalah BPUPK 1 dan Risalah BPUPK 2 tidak berdasarkan kata demi kata (woordelijk) dari notulen sidang (notulistisch verslag) autentik BPUPK, sehingga klaim Nugroho Notosutanto bahwa Naskah Persiapan merupakan sumber autentik, gugur.

\section{Penutup}

Koleksi Pringgodigdo dan Koleksi Yamin adalah sumber tertulis autentik tentang perumusan sejarah Pancasila sebagai dasar negara Indonesia merdeka dalam masa sidang pertama Badan Untuk Menyelidiki Usaha-usaha Persiapan Kemerdekaan Tanggal 29 Mei-1 Juni 1945, sedangkan Naskah Persiapan karya Muhammad Yamin bukan merupakan sumber tertulis autentik karena tidak dicetak kata demi kata (woordelijk) dari notulen sidang (notulistisch verslag) resmi BPUPK.

Sekretariat Negara perlu menerbitkan edisi pemutakhiran Risalah BPUPK yang didasarkan murni dari Koleksi Yamin dan Koleksi Pringgodigdo dengan mengeyampingkan Naskah Persiapan Undang-Undang Dasar 1945 karya Muhammad Yamin yang tidak autentik.

\section{Daftar Pustaka}

\section{Buku}

A.B. Kusuma, Lahirnya Undang-undang Dasar 1945, Badan Penerbit Fakultas Hukum Universitas Indonesia. Jakarta, 2009.

A.G. Pringgodigdo, Perjuangan Bangsa Indonesia Menegakkan Pancasila Dalam Masa Penjajahan/Pendudukan Jepang, Jakarta 
Tatanegara di Djawa Pada Waktu Pendudukan Djepang dari Bulan Maret sampai bulan Desember 1942, Jajasan Fonds Universitit Gadjah Mada, Jogjakarta, 1952.

J.C.T Simorangkir, Penetapan UUD Dilihat Dari Segi Ilmu Hukum Tata Negara Indonesia, Gunung Agung, Jakarta, 1984.

Lembaga Soekarno Hatta, Sejarah Lahirnya Undang-Undang Dasar 1945 dan Pancasila, Inti Idayu Press, Jakarta, 1986.

Moh. Hatta, Ahmad Subardjo Djojoadisurjo, et.al., Uraian Pancasila, Mutiara, Jakarta, 1984.

Muhammad Yamin, Naskah Persiapan Undang-undang Dasar 1945 Djilid 1, Prapantja, Djakarta, 1959.

Notosutanto, Nugroho, Proses Penyusunan Pancasila Dasar Negara, Balai Pustaka, Jakarta, 1981.

Saafroedin Bahar, Ananda B. Kusuma, dan Nannie Hudawati, Risalah Sidang Badan Penyelidik Usaha-udaha Persiapan Kemerdekaan Indonesia (BPUPKI) Panitia Persiapan Kemerdekaan Indonesia (PPKI) 28 Mei 1945-22 Agustus 1945, Sekretariat Negara, Jakarta, 1995.

Saafroedin Bahar dan Nannie Hudawati, Risalah Sidang Badan Penyelidik Usahaudaha Persiapan Kemerdekaan Indonesia (BPUPKI) Panitia Persiapan Kemerdekaan Indonesia (PPKI) 28 Mei 1945-22 Agustus 1945, Sekretariat Negara, Jakarta, 1998.

Soekarno, Lahirnja Pantja Sila: Boeng Karno Menggembleng Dasar-dasar Indonesia merdeka, Oesaha Penerbitan Goentoer, Jogjakarta, 1947.

Sukarno, Lahirnja Pantja-Sila, Departemen Penerangan, Djakarta, 1960.

\section{Dokumen}

Archivalia van Raden Mas mr Abdul Gaffar Pringgodigdo, destijds Secretaris van Staat van de Republiek Indonesië Nr. 5645 Zittingsverslagen, notulen en aantekeningen betreffende de vergaderingen van de Dokuritu Zyunbi Tyosa Kai (Badan untuk Menjelidiki Usaha-Usaha Persiapan Kemerdekaan) en de hieruit onstane Panitia Persiapan Kemerdekaan Indonesia.

Nr. 5646 Stukken bevattende concept-voorstellen voor de Grondwet van Indonesie, de landsverdediging, de staatfinancien, en de economie Nr. 5647 'Indonesia merdeka selekas-lekasnya' manifest zoals vastgesteid door de leden van de Dokuritu Zyunbi Tyosa Kai

\section{Website}

http://www.jstor.org/stable/41288761?origin=JSTOR-pdf, diakses tanggal 25 Januari 2017

https://openaccess.leidenuniv.nl/bitstream/1887/33293/9/03.pdf, diakses tanggal 25 Januari 2017 